\title{
Comparison of the protective efficiency of corrosion inhibitors in oilfield pipelines
}

\author{
I. S. Sivokon ${ }^{1}$ and N. N. Andreev ${ }^{2}$ \\ ${ }^{1}$ OJSC Transenergostroi, Derbenevskaya nab. 7, bldg. 10, Moscow, \\ 115114 Russian Federation \\ ${ }^{2}$ A. N. Frumkin Institute of Physical Chemistry and Electrochemistry, Russian Academy \\ of Sciences, Leninskii pr. 31, Moscow, 119071 Russian Federation \\ E-mail: issiv64@gmail.com
}

\begin{abstract}
This paper is the final article in the series published by the International Journal of Corrosion and Scale Inhibition. The series is dedicated to efficiency evaluation of protection provided by carbon dioxide corrosion inhibitors at oilfield pipelines in West Siberia where the inhibitor selection and efficiency supervision system issues are common in field-wide applications. Laboratory testing is an easy way to properly select corrosion inhibitors by performing a comprehensive set of procedures instead of making a couple of isolated tests trying to simulate most obvious corrosion environment features.
\end{abstract}

Key terms: oilfield pipelines, corrosion, inhibitors, testing techniques.

Received: November 25, 2013.

doi: $\underline{10.17675 / 2305-6894-2014-3-1-001-011}$

\section{Inhibitor protection practice and efficiency in West Siberia}

Nowadays, inhibition of low-carbon steel pipelines at oilfields is the most popular way of pipeline internal corrosion control. For example, among oil companies developing oil fields in West Siberia, TNK-BP protects over $50 \%$ of its pipelines by inhibition and Rosneft - over $40 \%$.

However, lab testing techniques, field pilot tests, and corrosion monitoring carried out to supervise corrosion inhibitors industrial applications are not perfect. As a result, widely used inhibitor protection designed to control pipeline internal corrosion fails to ensure failure-free operation and prevent accidents and incidents caused by leaks due to internal corrosion.

The pipeline cathodic protection against external corrosion can serve as an example of positive experience. Gazprom's and Transneft's trunk pipelines are safely operated due to proper observance of regulations combined with regular inspections and repairs.

Figures 1 and 2 show 2011-2012 failures and incidents caused by through-wall internal corrosion at inhibited and non-inhibited pipelines at West Siberian oilfields in Nizhnevartovsk and Oktyabrsk regions, Khanty-Mansi autonomous district.

Failure and incident statistics demonstrate that the inhibited pipelines with the service life of up to 5 years and from 6 to 10 years have almost the same rate of through-wall 
internal corrosion as the pipelines with no inhibitor protection at all. It means that the internal corrosion rate at certain sections of the inhibited pipelines is $1 \mathrm{~mm}$ per year or more. However, the corrosion inhibitors tests demonstrate a protective capability of at least $90 \%$. Moreover, the results of corrosion monitoring that demonstrate the pipeline corrosion rate evaluated by gravimetric techniques using coupons, electrical resistance sensors, and other pipeline corrosion monitoring tools range from 0.01 to $0.2 \mathrm{~mm}$ per year when inhibitors are applied. Occasionally, corrosion monitoring results reach $0.5 \mathrm{~mm}$ per year. These results do not correlate with the through corrosion data observed in accidents and incidents.

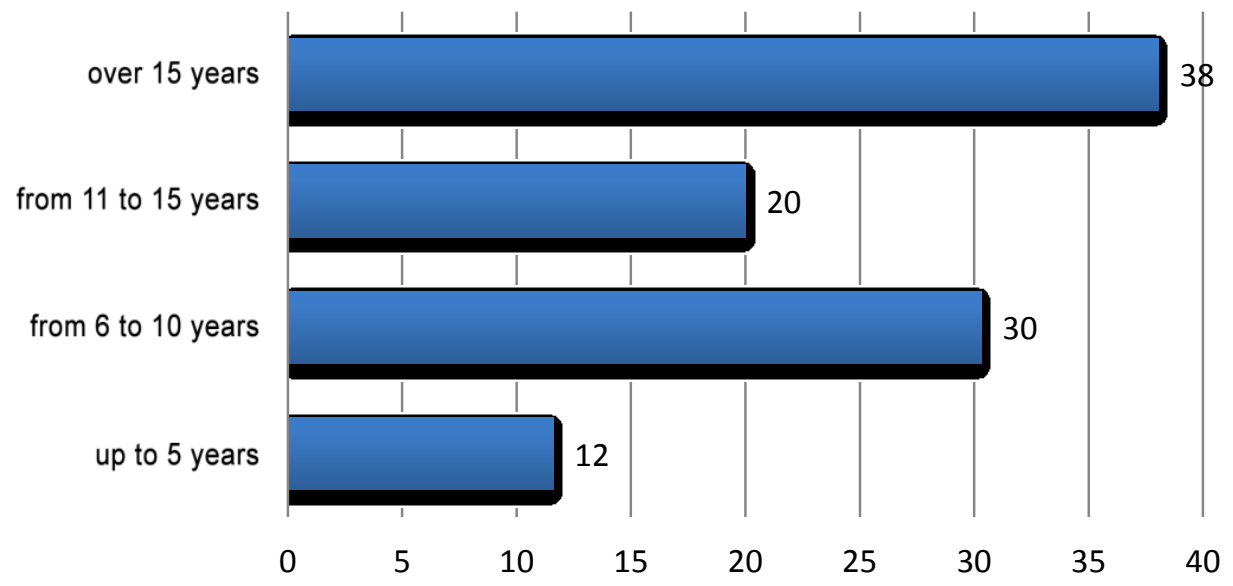

Fig. 1. Accidents and incidents (in per cent) caused by internal corrosion of inhibited oilfield pipelines in West Siberia (2011-2012) depending on years in service.

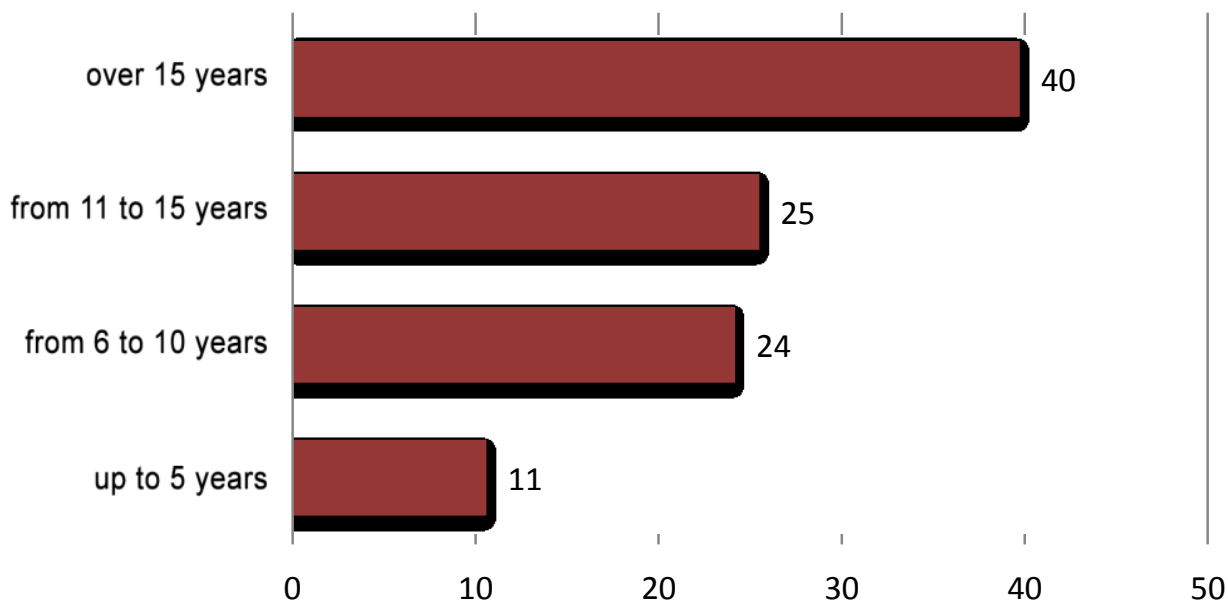

Fig. 2. Accidents and incidents (in per cent) caused by internal corrosion of non-inhibited oilfield pipelines in West Siberia (2011-2012) depending on years in service.

There is an excuse with old inhibitor protected pipelines with the service life exceeding 10 years, where the high corrosion rate is explained by the fact that inhibitor 
protection was not applied during most of their operational time as decisions on inhibitor applications were late. In cases of pipelines with less than 10 years in service, when inhibition protection was applied on a regular basis, it usually started at the time of the pipeline commissioning. At these pipelines the high through internal corrosion rate is a direct result of miscalculations and inefficient corrosion inhibitor lab and field tests performed when inhibitors were selected for industrial-scale application.

Inhibitor protection as a business process includes several key stages:

- Corrosion inhibitor lab testing carried out in order to select most effective products to use in pipelines;

- Field pilots to select most effective products out of those chosen at the lab test stage. Corrosion inhibitor efficiency (protective action) during field testing is evaluated based on corrosion monitoring results;

- Industrial application to be efficiently controlled by corrosion monitoring. One of corrosion industrial application monitoring objectives is to evaluate the current protective action and receive reliable information to be used for the inhibition process correction:

- Adjustment of corrosion inhibitor concentration;

- Corrosion inhibitor application process correction;

- Corrosion inhibitor efficiency supervision under all application conditions;

- Justification of corrosion inhibitor replacement, in case of insufficient protective action.

It is expected that an efficient inhibition business process will result in no corrosioncaused leaks in pipelines with less than 10-15 years of service. In other words, a larger share of accident and incidents should shift towards pipelines with over $10-15$ years of service life.

\section{Selection procedures for industrial application of corrosion inhibitors}

Russian oil companies follow standard procedures for selecting corrosion inhibitors intended for industrial application (ref. example in [2]). In general, the procedures are in line with the business process stages described above.

Proper selection of an inhibitor for the follow-up field pilot test is not the only purpose of lab testing; it is also necessary to identify certain corrosion inhibitor advantages and shortcomings as well as special application requirements. During the lab testing, specific oilfield pipelines operation conditions, both regular and spontaneous, are simulated. Besides, tests are performed to reduce costs associated with field pilot testing.

In general, field tests are conducted at a certain section of a typical operation condition pipeline system. Below is the list of major stages and sequence of the stages during field testing: 
1. Shut-down of the previous corrosion inhibitor injection; flushing;

2. Measurement of the reference corrosion rate;

3. Delivery of the specific concentration inhibitor to the pipeline section in the batch treatment/continuous injection mode;

4. Installation of coupons and/or other sensors and return to the tested corrosion inhibitor concentration. The gravimetric technique is practically the main method of the corrosion rate measurement.

Any field pilot test is to be considered successful if the corrosion inhibitor demonstrates a protective action of at least $90 \%$ minimum. The pilot results are applied to the whole pipeline system within the specific field or producing company. Adjustments are introduced during industrial-scale application: the inhibitor concentration may vary based on the corrosion monitoring results. The coupons corrosion rate measured by gravimetric techniques is also accounted for.

Decisions on efficiency and industrial application feasibility are made proceeding from the lab test results that are based on simulation of just a few of the inhibitor pipeline application conditions. The field test results that also do not include all possible conditions of corrosion processes are taken into consideration as well. The real field application monitoring is often limited because of its high cost and does not ensure fair judgment of the current corrosion inhibitor protection efficiency.

Since it never happens that one and the same inhibitor is used for over 5 years at the same pipelines on a regular basis, it is impossible to associate accidents and incidents at the inhibited pipelines with the certain corrosion inhibitor problems provided pipelines are operated for 5-10 years. However, laboratory, field test and corrosion monitoring results never indicate a corrosion rate of over $1 \mathrm{~mm}$ per year, which is the cause of through corrosion damage of pipeline walls or welded joints resulting in leaks. The reported leaks leave no doubt that the real world corrosion rates are higher.

An assumption can be made based on the data provided above: the corrosion inhibitor selection methodology used nowadays does not provide enough information as well as selection techniques are not efficient and do not account for real pipeline application conditions. This goes for all key stages of the corrosion inhibitor industrial application:

1. Lab testing;

2. Field pilot tests;

3. Corrosion monitoring during field tests and industrial application.

\section{Corrosion inhibitor lab testing}

Samples of corrosion inhibitors widely used for pipeline inhibition at oil fields in West Siberia were used for the protective action testing. The corrosion inhibitors and their properties are presented in Table 1. On the one hand, the selected inhibitors showed the best results in the traditional lab tests [1], demonstrating at least $90 \%$ protective action during field tests. On the other hand, the inhibitors have a long history of monitoring and a 
large statistical record evidencing their insufficiency that resulted in multiple through corrosion leaks recorded in oilfield pipelines (Fig. 1 and Fig. 2).

Table 1. Corrosion inhibitors tested for their protective capacity under various conditions.

\begin{tabular}{|c|c|c|c|c|c|}
\hline \# & Description & Manufacturer \& Specs & $\begin{array}{l}\text { Freezing } \\
\text { point, }{ }^{\circ} \mathrm{C}\end{array}$ & $\begin{array}{c}\text { Density } @ \\
20^{\circ} \mathrm{C}, \mathrm{g} / \mathrm{cm}^{3}\end{array}$ & $\begin{array}{l}\text { Active base } \\
\text { content, } \%\end{array}$ \\
\hline 1 & Skimol 2111 & $\begin{array}{c}\text { Mirriko, specification } \\
\text { 2485-002-94296805-2008 } \\
\text { modifications } 1 \text { and } 2\end{array}$ & Below -50 & $0.99 \pm 0.03$ & 25 maximum \\
\hline 2 & Sonkor 9011 & $\begin{array}{l}\text { Neftekhim experimental } \\
\text { plant, specification 2415- } \\
\text { 028-00151816-2009 }\end{array}$ & Below -50 & $0.92 \pm 0.03$ & 20 minimum \\
\hline 3 & Azol 5010A & $\begin{array}{l}\text { Kotlas chemical plant, } \\
\text { specification 2485-045- } \\
00205423-2003 \\
\text { modification } 1\end{array}$ & Below -45 & 0.86 minimum & 25 minimum \\
\hline 4 & Cormaster 1035 & $\begin{array}{c}\text { Master Chemicals, } \\
\text { specification 2485-002- } \\
50622652-2002 \\
\text { modifications 1-3 }\end{array}$ & Below -50 & $0.85 \pm 0.06$ & $25 \pm 5$ \\
\hline 5 & Corexit 1003 & $\begin{array}{c}\text { Nalco, specification 39- } \\
\text { 12966446-OП-004-98 } \\
\text { modifications 1-3 }\end{array}$ & Below -50 & not specified & $21 \pm 3$ \\
\hline 6 & Sonkor 9920 & $\begin{array}{l}\text { Neftekhim pilot plant, } \\
\text { specification 2458-030- } \\
00151816-2004 \\
\text { modification } 1\end{array}$ & Below -50 & $0.92 \pm 0.04$ & $45 \pm 3$ \\
\hline 7 & Azol SI130 & $\begin{array}{c}\text { Kotlas chemical plant, } \\
\text { specification 2458-048- } \\
\text { 00205423-2011, including } \\
\text { modification } 1\end{array}$ & Below -50 & $0.94 \pm 0.04$ & 23.0 minimum \\
\hline
\end{tabular}

The corrosion inhibitors protective action test results received using the test solution at NizhnevartovskNIPIneft [1] corrosion laboratory are provided in Table 2. The tests were conducted in accordance with the following procedure:

A. Carbon dioxide formation water model, $17.8 \mathrm{~g} / 1$ salinity, was used as aggressive media - an average composition at Samotlor field. The test solution composition in $\mathrm{g} / \mathrm{l}: \mathrm{NaCl}-17.0 ; \mathrm{CaCl}_{2}-0.17 ; \mathrm{NaHCO}_{3}-0.63$;

B. The protective action (protective effect) of the corrosion inhibitors is evaluated using the polarization resistance method at the lab installation consisting of a 
pressurized $\mathrm{CO}_{2}$ vessel, gas flow control valve, three cells equipped with two electrodes each, and magnetic stirrers. The corrosion rate measurements are made using the ACM corrosion test station (UK); the electrodes are made of AISI 1018 steel (steel grade 20). Manufacturer: Rohrback Cosasco.

C. Prior to the test, the electrodes are held in xylene for 3-5 minutes, dried using the filter paper, given a mirror-like polish by \#0 finishing paper, and degreased using ethanol. The sample is attached to the electrode holders with rubber seals insulation.

D. Prior to the test, the cells are vented with $\mathrm{CO}_{2}$ for 15 minutes, filled with the model formation water, and then the electrodes are attached. $\mathrm{CO}_{2}$ is continuously supplied to the cells; gas partial pressure: 0.9 atm; test temperature: plus $40^{\circ} \mathrm{C}$, test duration: 6 hours.

E. The corrosion inhibitor protective action evaluation in the carbon dioxide environment by the polarization resistance method consisting of the following consecutive steps:

1. Cells blow-off with $\mathrm{CO}_{2}$;

2. Filling the cells with model formation water;

3. Attaching the electrodes to the holder, the electrodes introduction into the cells;

4. Determination of the corrosion reference rate;

5. Corrosion inhibitor injection into the cells using a micro syringe;

6. Evaluation of the corrosion rate after injection of the inhibitor as the values are stabilized.

In addition, the paper [1] defines the inhibitor protective action in the oil-water system that simulates environment of the laminated fluid flow in the oilfield gathering systems, as well as the inhibitor transfer from oil into water. The technique described above was used with the following variations:

A. A 1 liter glass vessel was filled with model formation water $(90 \%)$ and noninhibited oil (10\%).

B. As the corrosion rate was stabilized, some estimated amount of the inhibitor was added to the oil layer using the micro syringe, and then the electrodes corrosion rate was recorded.

C. Based on the electrodes corrosion rate fluctuations (converted into the protective action), conclusions on efficiency of the inhibitor transition from oil into water were made.

As the authors of the paper [1] conclude, this technique is not applicable for efficiency evaluation regarding inhibitors soluble in oil and poorly dispersing in water (for example, Azol 5010A).

Studies of the corrosion inhibitor test conditions were carried out at A. N. Frumkin Institute of Physical Chemistry and Electrochemistry, Russian Academy of Sciences. 
Corrosion inhibitor protective actions in various testing environments simulating corrosion processes at oilfield pipelines were investigated [3-7]. Table 3 shows the results for water pipeline operation conditions. High water-cut fluid transportation infield pipelines results are provided in Table 4.

Table 2. Corrosion inhibitor test at NizhnevartovskNIPIneft Institute corrosion laboratory.

\begin{tabular}{cccccc}
\hline \multirow{2}{*}{$\#$} & Description & \multicolumn{2}{c}{ Solubility } & \multicolumn{2}{c}{ Protective action, \%, at 20 g/ton } \\
\cline { 3 - 6 } & & Water & Oil & Model solution & Oil-water system \\
\hline 1 & Skimol 2111 & Self-dispersible & Soluble & $97.1 \pm 0.2$ & $97.9 \pm 0.7$ \\
2 & Sonkor 9011 & Self-dispersible & Non-dispersible & $96.1 \pm 0.4$ & $97.4 \pm 0.4$ \\
3 & Azol 5010A & Poorly dispersible & Soluble & $90.1 \pm 0.4$ & N/A \\
4 & Cormaster 1035 & Dispersible & Soluble & $95.7 \pm 0.25$ & $94.2 \pm 0.4$ \\
5 & Corexit 1003 & Soluble & Soluble & $90.1 \pm 2.7$ & $90.1 \pm 2.8$ \\
6 & Sonkor 9920 & Dispersible & Non-dispersible & $96.1 \pm 0.4$ & $95.4 \pm 0.6$ \\
7 & Azol CI130 & Self-dispersible & Soluble & $98.2 \pm 0.2$ & $97.1 \pm 0.8$ \\
\hline
\end{tabular}

Table 3. Corrosion inhibitor protective action measurement results. Oilfield water pipelines in model environment [3].

\begin{tabular}{|c|c|c|c|c|c|c|c|}
\hline $\begin{array}{l}\text { Lab test technique } \\
\text { and conditions }\end{array}$ & $\frac{\Xi}{\bar{a}}$ & 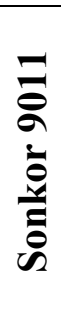 & $\frac{\mathbb{0}}{\stackrel{0}{8}}$ & 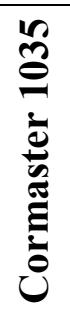 & 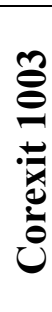 & 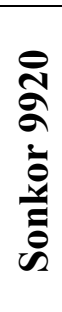 & $\stackrel{\stackrel{0}{\Xi}}{\frac{0}{8}}$ \\
\hline Bubble test, $25^{\circ} \mathrm{C}, 50 \mathrm{mg} / 1$ & 70 & 64 & 5 & 73 & 49 & 76 & $91^{*}$ \\
\hline U-shaped cell, $25^{\circ} \mathrm{C}, 50 \mathrm{mg} / \mathrm{l}$ & 73 & 57 & 47 & 78 & 83 & 23 & 30 \\
\hline Rotating cylinder, $25^{\circ} \mathrm{C}, 25 \mathrm{mg} / 1$ & 90 & 80 & N/A & 63 & 81 & 81 & 78 \\
\hline Rotating cage, $25^{\circ} \mathrm{C}, 25 \mathrm{mg} / 1$ & 92 & 83 & 99 & 93 & 88 & 69 & 76 \\
\hline $\begin{array}{c}\text { Running circulating loop, } 25^{\circ} \mathrm{C} \text {, } \\
50 \mathrm{mg} / \mathrm{l} \text {, flow rate } 1 \mathrm{~m} / \mathrm{s}\end{array}$ & 91 & 72 & 52 & 80 & 56 & 68 & 60 \\
\hline $\begin{array}{l}\text { Corrosion inhibitor applicability } \\
\text { for oilfield water pipelines, } \\
\text { score** }\end{array}$ & 9 & 3 & 2 & 4 & 5 & 2 & 4 \\
\hline
\end{tabular}

* - In the case of Azol CI130 corrosion inhibitor, the test was conducted at $8^{\circ} \mathrm{C}$.

** - Scoring system: $1^{\text {st }}$ place -3 points, $2^{\text {nd }}$ place -1 point. 
Table 4. Corrosion inhibitor protective action measurement results. Oilfield pipelines designed for transportation of two-phase high water-cut fluid.

\begin{tabular}{|c|c|c|c|c|c|c|c|}
\hline $\begin{array}{l}\text { Lab testing technique } \\
\text { and conditions }\end{array}$ & 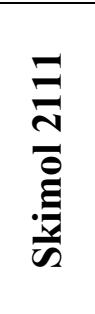 & 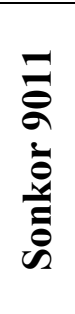 & 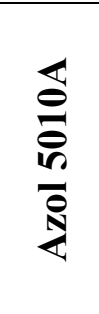 & 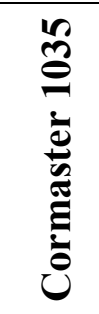 & 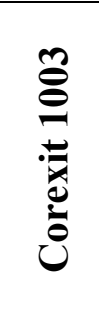 & 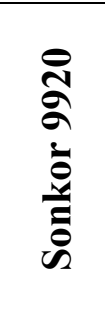 & 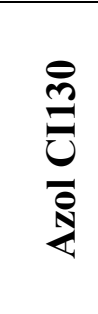 \\
\hline Bubble test, $25^{\circ} \mathrm{C}, 25 \mathrm{mg} / 1$ & 96 & 88 & $\mathrm{~N} / \mathrm{A}$ & 98 & $\mathrm{~N} / \mathrm{A}$ & 93 & $\mathrm{~N} / \mathrm{A}$ \\
\hline Bubble test, $45^{\circ} \mathrm{C}, 50 \mathrm{mg} / \mathrm{l}$ & 96 & 91 & N/A & 96 & $\mathrm{~N} / \mathrm{A}$ & 97 & $\mathrm{~N} / \mathrm{A}$ \\
\hline U-cell, $25^{\circ} \mathrm{C}, 50 \mathrm{mg} / 1$ & 90 & 38 & 0 & 79 & 85 & 88 & 97 \\
\hline U-cell, $45^{\circ} \mathrm{C}, 50 \mathrm{mg} / 1$ & 97 & 53 & 43 & 95 & 91 & 89 & 99 \\
\hline Rotating cylinder, $25^{\circ} \mathrm{C}, 25 \mathrm{mg} / 1$ & 82 & 88 & $\mathrm{~N} / \mathrm{A}$ & $\mathrm{N} / \mathrm{A}$ & $69^{*}$ & $\mathrm{~N} / \mathrm{A}$ & $\mathrm{N} / \mathrm{A}$ \\
\hline Rotating cylinder, $45^{\circ} \mathrm{C}, 50 \mathrm{mg} / 1$ & 84 & 91 & $\mathrm{~N} / \mathrm{A}$ & 86 & $44^{* *}$ & $93^{* * *}$ & $36^{* * *}$ \\
\hline Rotating cage, $25^{\circ} \mathrm{C}, 25 \mathrm{mg} / \mathrm{l}$ & 45 & 88 & 77 & 85 & 72 & 83 & 83 \\
\hline Rotating cage, $45^{\circ} \mathrm{C}, 25 \mathrm{mg} / \mathrm{l}$ & 99 & 94 & 94 & 97 & 91 & 93 & 86 \\
\hline $\begin{array}{c}\text { Running circulating loop, } 25^{\circ} \mathrm{C} \text {, } \\
50 \mathrm{mg} / \mathrm{l} \text {, flow rate } 1 \mathrm{~m} / \mathrm{s}\end{array}$ & 70 & 90 & 40 & 85 & 40 & 56 & 64 \\
\hline $\begin{array}{c}\text { Running circulating loop, } 45^{\circ} \mathrm{C} \text {, } \\
50 \mathrm{mg} / 1, \text { flow rate } 1 \mathrm{~m} / \mathrm{s}\end{array}$ & $\mathrm{N} / \mathrm{A}$ & 69 & 40 & 67 & 46 & 51 & 51 \\
\hline $\begin{array}{c}\text { Running circulating loop, } 25^{\circ} \mathrm{C} \\
50 \mathrm{mg} / \mathrm{l}, \text { flow rate } 6 \mathrm{~m} / \mathrm{s}\end{array}$ & 46 & 52 & 65 & 47 & 44 & 22 & 10 \\
\hline $\begin{array}{l}\text { Corrosion inhibitor applicability } \\
\text { for oilfield water pipelines, points }\end{array}$ & 9 & 14 & 5 & 10 & 3 & 8 & 9 \\
\hline
\end{tabular}

Based on the corrosion inhibitors test results under oilfield water pipelines operational conditions, the following conclusions concerning inhibitor efficiency, advantages and shortcoming can be made:

Skimol 2111 shows most stable results in various tests. This corrosion inhibitor is expected to produce a minimum number of issues during industrial application for water pipeline corrosion protection.

Cormaster 1035, Sonkor 9011, Corexit 1003, Sonkor 9920, and Azol CI130. During the tests in the model environment containing up to $0.2 \mathrm{mg} / 1$ of $\mathrm{O}_{2}$ and featuring a high flow rate $(1 \mathrm{~m} / \mathrm{s}$ minimum), insufficient protection was observed. As a result, the conclusion can be made that accidents and incidents are possible at industrial application 
due to through corrosion at heavily loaded sections of the protected pipelines and in case oxygen enters the transported high salinity fluid.

Azol 5010A is the only corrosion inhibitor out of all tested inhibitors that is poorly dispersed in water, e.g. it is oil-soluble; during one of the tests using the rotating cage it showed $99 \%$ protective action. In the rotating case, a ratio between the coupon surface area and the area of the vessel surface that contains the coupon, is very close to 1 . Therefore, there was enough inhibitor to form the film both on the coupon and on the vessel surface. As it forms a robust protection film, this corrosion inhibitor should be potentially considered as the most efficient one. But this potential can be reached only by the batch treatment of the protected pipelines using high concentrations of the corrosion inhibitor or injection of corrosion inhibitor plugs. Hence, corrosion monitoring should be arranged accounting for the specific features of this corrosion inhibitor to identify the protective film presence or absence at the critical sections of the pipeline system.

Based on results of the corrosion inhibitors tests for operation conditions at oilfield pipelines used for high water-cut well production transportation, the following conclusions concerning inhibitors efficiency, advantages and shortcoming can be made:

Sonkor 9011 (14 points) demonstrated best results for infield gathering lines systems, but low protective action observed during the U-cell test shows the possibility of insufficient corrosion protection effect by this inhibitor in turbulent conditions with high flow rates. These circumstances require follow-up research and special attention during industrial application.

Skimol 2111 (9 points), Cormaster 1035 (10 points) and Azol CI130 (9 points) show stable results during various tests, just as in case with the water pipelines. Low efficiency at the high flow rate $(6 \mathrm{~m} / \mathrm{s})$ is a shortcoming. Low efficiency at high flow rates was demonstrated by all corrosion inhibitors, except Azol 5010A.

Corexit 1003 (3 points) and Sonkor 9920 (8 points) show high protective action. Nonetheless, this protection effect decreases significantly with high flow rates. That was observed during the running circulating loop test. Accordingly, issues with the inhibition efficiency are possible in protection of pipelines with flow rates over $1 \mathrm{~m} / \mathrm{s}$ and inhibitor concentrations insufficient for these conditions.

Azol 5010A (5 points) has not demonstrated best results in any test, except for the running circulating loop test with flow rate of $6 \mathrm{~m} / \mathrm{s}$, and is considered the least applicable inhibitor to use at flow-line system. As in case with the water pipelines, this inhibitor can only be applied for batch or plug injections as well as at the pipelines with the turbulent fluid flow when oil contacts every section of the pipe inner surface ensuring the corrosion inhibitor delivery to the inner surface of the pipeline. If a pipeline is operated with a flow rate exceeding $3-4 \mathrm{~m} / \mathrm{s}$, this inhibitor has no alternatives among inhibitors on the testing list. 


\section{Conclusions}

The results of corrosion inhibitors resting under conditions that occur during oilfield pipelines operation at the oilfields in West Siberia show that industrially applied corrosion inhibitors show significant decrease in efficiency at certain conditions that are not usually investigated in standard lab and field tests. Besides, the inhibitor protective action decrease can be intensified by multiple times due to a lower corrosion inhibitor concentration caused by lack of information received after corrosion monitoring, as well as due to cost reduction requirements.

Insufficient corrosion inhibitors efficiency identified during industrial applications is mainly caused by the factors listed above.

Proper selection of most efficient inhibitors, current efficiency monitoring and correct injection techniques are the only way to reduce accidents and incidents risks and ensure failure-free operation of pipelines for at least 15-20 years. However, large-scale pilots and intensive field monitoring increase oil companies' inhibition costs by $10-20 \%$. Under present-day conditions this kind of extra budget requires a profound economic justification based on reliable experimental data.

Comprehensive laboratory tests designed to measure inhibitor protection action under all conditions of corrosion processes can be:

- A tool for benchmarking various inhibitor efficiency;

- A fast and inexpensive technique to study inhibitor protective properties under various operational conditions. The data may be used then to adjust the application technology and corrosion monitoring methods and scope;

- A means for the selective quality control of commercially available inhibitors. The quality control will not only ensure a formal compliance with relevant specifications, but will check whether the protective properties match the corrosion conditions identified during lab tests and field pilots performed prior to industrial field-wide applications.

\section{References}

1. Rezul'taty vkhodnogo kontrolya kachestva ingibitorov korrozii (Results of final inspection of corrosion inhibitor quality), NizhnevartovskNIPIneft report, $36 \mathrm{pp}$., Nizhnevartovsk, 2011 (in Russian).

2. Inhibition of oil field pipelines, TNK-BP Standard, Moscow, 2007.

3. I. S. Sivokon and N. N. Andreev, Int. J. Corros. Scale Inhib., 2012, no. 1, 65. doi: 10.17675/2305-6894-2012-1-1-065-079

4. I. S. Sivokon, D. B. Verchok and N. N. Andreev, Int. J. Corros. Scale Inhib., 2012, no. 2 , 130. doi: $10.17675 / 2305-6894-2012-1-2-130-145$

5. N. N. Andreev, N. G. Anufriev and I. S. Sivokon, Int. J. Corros. Scale Inhib., 2013, no. 1, 17. doi: $\underline{10.17675 / 2305-6894-2013-2-1-017-029}$ 
6. I. S. Sivokon, Y. B. Makarychev, Y. A. Kuzenkov and N. N. Andreev, Int. J. Corros. Scale Inhib., 2013, no. 3, 203. doi: 10.17675/2305-6894-2013-2-3-203-215

7. I. A. Gedvillo, S. V. Oleynik, I. S. Sivokon and N. N. Andreev, Int. J. Corros. Scale Inhib., 2013, no. 4, 287. doi: 10.17675/2305-6894-2013-2-4-287-303

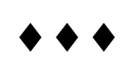

